\title{
Can inhibiting insulin/IGF signaling with dietary carbohydrate restriction play a role in treatment/prevention of cancers?
}

\author{
Eugene J Fine ${ }^{1 *}$, C Segal-Isaacson ${ }^{1}$, Silvia Herzkopf ${ }^{2}$, Joseph Sparano ${ }^{3}$, Maria Romano ${ }^{2}$, Richard Feinman ${ }^{4}$, \\ Nora Tomuta², Amanda Bontempo ${ }^{2}$, Abdissa Negassa ${ }^{5}$
}

From Metabolism, Diet and Disease 2014: Cancer and metabolism

Washington DC, USA. 28-30 May 2014

\section{Background}

Hyperinsulinemia, hyperglycemia, and obesity have been identified as risk factors for a variety of cancers [1]. Insulin inhibition (INSINH) can potentially limit cancer growth by factors including ketosis [2], and apoptosis secondary to fatty acid synthase inhibition [3] as well as intracellular potassium depletion [4]. Furthermore, dysregulation of many signaling proteins downstream of the insulin/IGF receptors such as PI3K/Akt, mTOR (inhibition) and AMPK (amplification) is a major area of drug target development $[5,6]$. We performed a four week INSINH diet in patients with advanced cancers to study safety/feasibility and also to examine a change in ${ }^{18} \mathrm{~F}$-2-fluoro, 2-deoxyglucose (FDG) uptake on PET scan as a surrogate measure for tumor response.

\section{Methods}

Eligible patients had failed or refused $\geq 2$ standard chemotherapy courses. Exclusions included concurrent chemotherapy, end-organ disease, hypoglycemic medications, difficult compliance, or BMI $<20$. A supervised INSINH diet restricted starches and sugars for 28 days, and was monitored weekly for macronutrient intake, body weight, [glucose] [BHB], [insulin], [IGF1,2]. An exit four-week PET was obtained for comparison with the baseline scan.

\section{Results}

Ten subjects with diverse cancers completed $\geq 26$ days of INSINH without associated unsafe adverse effects. Mean caloric intake decreased $(35 \pm 6) \%$ vs. predicted requirements despite our best efforts to encourage increased food

\footnotetext{
${ }^{1}$ Nuclear Medicine, Albert Einstein College of Medicine, Bronx, NY, USA Full list of author information is available at the end of the article
}

consumption. Weight loss (median 4\%, range 0.0-6.1\%) was not judged a health risk in any subject. Mild, reversible side effects included constipation $(n=2)$, transient fatigue $(n=5)$, and leg cramps $(n=2)$. Among nine patients with pre-trial progressive disease (PD) five demonstrated post-trial stable disease or partial remission (SD/ PR) on PET. SD/PR correlated with three-fold higher ketosis compared to those with continued PD $(n=4),(p<0.02)$, but was uncorrelated with reduced calorie intake $(\mathrm{p}=0.45)$ or weight loss $(\mathrm{p}=0.81)$. Insulin correlated inversely with ketosis $(\mathrm{r}=0.62, \mathrm{p}=0.026)$, but did not correlate with IFG (1 or 2$)$.

\section{Conclusions}

Preliminary pilot data in ten subjects demonstrated that an INSINH diet is safe and feasible in selected patients with advanced cancer. The extent of ketosis, but neither calorie deficit nor weight loss correlated with SD/PR. The small sample size requires further study. Further exploration is also required to evaluate an insulin inhibiting diet's: 1. mechanism in relation to calorie restriction; 2 . role as an adjunct to metabolic or cytotoxic therapies; 3 . long-term value to reduce overall cancer risk.

\footnotetext{
Acknowledgements

This work was supported by the State University of New York Research Foundation and the Robert and Veronica Atkins Foundation. This publication also was supported in part by CTSA grants UL1RR025750, KL2RR025749 (gs4), and TL1RR025748 from the National Center for Research Resources, a component of the National Institutes of Health, and the National Institutesof Health Roadmap for Medical Research.

\section{Authors' details}

${ }^{1}$ Nuclear Medicine, Albert Einstein College of Medicine, Bronx, NY, USA.

${ }^{2}$ Radiation Oncology, Montefiore Medical Center, Bronx, NY, USA. ${ }^{3}$ Medicine, Montefiore Medical Center, Bronx, NY. ${ }^{4}$ Cell Biology, SUNY-Downstate
} 
Published: 28 May 2014

\section{References}

1. Lann D, LeRoith D: The role of endocrine insulin-like growth factor-I and insulin in breast cancer. J Mammary Gland Biol Neoplasia 2008, 13:371-379.

2. Fine EJ, Miller A, Quadros EV, Sequeira JM, Feinman RD: Acetoacetate reduces growth and ATP concentration in cancer cell lines which overexpress uncoupling protein 2. Cancer Cell International 2009, 9:14.

3. Zhou W, Simpson PJ, McFadden JM, et al: Fatty acid synthase inhibition triggers apoptosis during $\mathrm{S}$ phase in human cancer cells. Cancer Res 2003, 63:7330-7337.

4. Bortner CD, Sifre Ml, Cidlowski JA: Cationic gradient reversal and cytoskeleton-independent volume regulatory pathways define an early stage of apoptosis. J Biol Chem 2008, 283:7219-7229.

5. Yao JC, Lombard-Bohas C, Baudin E, Kvols LK, Rougier P, Ruszniewski $P$, et al: Daily oral everolimus activity in patients with metastatic pancreatic neuroendocrine tumors after failure of cytotoxic chemotherapy: a phase II trial. J Clin Oncol 2010, 28:69-76.

6. Luo Z, Zang M, Guo W: AMPK as a metabolic tumor suppressor: control of metabolism and cell growth. Future Oncol 2010, 6:457-470.

doi:10.1186/2049-3002-2-S1-031

Cite this article as: Fine et al: Can inhibiting insulin/IGF signaling with dietary carbohydrate restriction play a role in treatment/prevention of cancers? Cancer \& Metabolism 2014 2(Suppl 1):031.

\section{Submit your next manuscript to BioMed Central and take full advantage of:}

- Convenient online submission

- Thorough peer review

- No space constraints or color figure charges

- Immediate publication on acceptance

- Inclusion in PubMed, CAS, Scopus and Google Scholar

- Research which is freely available for redistribution

Submit your manuscript at www.biomedcentral.com/submit 